\title{
A Critical analysis of the EU legal provisions on Terrorism
}

Maria O'Neill,

BCL, LLM, M.Ed., Solicitor,

Lecturer in Law,

University of Abertay Dundee,

Bell Street,

Dundee DD1 1HG,

Scotland.

Tel: 00441382308421

Fax: 00441382308400

E-mail: m.oneill@ abertay.ac.uk

This article operates as an introduction to the EU legal provisions on terrorism, to include, not just its content, but also its very important legal context. The potential for the development of this very important area of law is hampered by the legal framework within which it operates, and the variety of actors operating in this field at an EU level. This paper is addressed to an audience who is familiar with the policy area of terrorism, but is perhaps less familiar with the EU legal provisions and legal framework in this area.

\section{Introduction}

2. The EU Terrorism Provisions

3. The EU legal framework in which the terrorism provisions are set

4. Proposals for reform under the proposed EU Constitution

5. Conclusion

\section{Introduction}

The European Union classifies terrorism under the heading of EU policy on Justice and Home Affairs (JHA). Its current focus in this area is in what is known as the Hague Programme, which covers ten priority action points, one of which is terrorism. ${ }^{1}$ The Hague programme, which was launched on the $10^{\text {th }}$ May 2005, states that the "Union's attention must focus on different aspects of prevention, preparedness and

\footnotetext{
${ }^{1}$ 1. Fundamental Rights and citizenship, 2. the fight against terrorism, 3. Migration management, 4. Internal borders, external borders and visas, 5. a common asylum area, 6 . Integration: the positive impact of migration on our society and economy, 7. Privacy and security in sharing information, 8 . the fight against organised crime, 9. Civil and criminal justice: an effective European area of justice for all, and 10 . Freedom, Security and Justice: sharing responsibility and solidarity.
} 
response," to include "the reduction of access to financial and economic resources by terrorists". In order to facilitate the development of EU strength in this area, there is a need to exchange "information relevant to the investigation of terrorist activities", and the "protection of critical infrastructure", to include the creation of a "Critical Infrastructure Warning Information Network (CIWIN)", together with policies for the support of "victims of terrorist acts".

The Tampere European Council of October 1999 placed the objective of the "progressive establishment of the area of freedom, security and justice" "at the head of the Union's political agenda and set a very ambitious programme". ${ }^{3}$ This approach was reinforced at the Santa Maria de Feira European Council in June 2000.

The structure of the European Union created by the Maastricht Treaty ${ }^{4}$ caused much concern amongst legal academics, to include the nature of the law in this area, the legal tools being used, and the lack of adequate human rights protection in this area. A widely adopted legal interpretation of the situations was given by Curtain $^{5}$ when she described the (then) new EU as having a three pillar structure, much as an ancient Greek temple, with the first pillar being the largest and most developed EC, benefiting from the principles of supremacy and direct effect, EC law having a complete and almost immediate effect within the jurisdictions of all of the member states of the EC. The second pillar, was to be known as the Common Foreign and Security Policy (CFSP), dealing with issues such as diplomacy, and what was to become the European Security and Defence Identity (ESDS), which has since lead to the creation and operation of EUFOR, ${ }^{6}$ with the third pillar being then known as Justice and Home Affairs (JHA). The then JHA pillar, now known since the Amsterdam Treaty in 1997 as the Police and Judicial Co-operation Pillar, is where anti-terrorist measures would be located, although there would be times when there would be a blurring of the boundary line between JHA provisions and the other two pillars, particularly with regard to the Free Movement of Capital, one of the EC's core principles with the

\footnotetext{
${ }^{2}$ The Hague Programme: Ten priorities for the next five years, A partnership for European renewal 2. A Union against terrorism; The fight against terrorism, Working toward a global response, available from the Europa website (http://www.europa.eu.int).

${ }^{3}$ Communication from the Commission to the council and the European Parliament Area of Freedom, Security and Justice: Assessment of the Tampere programme and future orientation, (SEC (2004) 680 and SEC(2004)693, Brussels 2.6.2004, COM (2004)401 final

${ }^{4}$ Treaty on European Union, O.J. C191, $29^{\text {th }}$ July 1992

${ }^{5}$ Curtin D, "The Constitutional Structure of the Union: a Europe of bits and pieces" (1993) 30 CMLRev 17

${ }^{6}$ The small but active EU Military Operation in Bosnia and Herzegovina
} 
money laundering legal provisions being dealt with using the EC legal tools of directives.

\section{The EU Terrorism Provisions}

While a writer on the political development on the EU's provisions dealing with terrorism might focus on the European Council Declaration of the $25^{\text {th }}$ March 2004 on the seven strategic objectives for the EU's Action against Terrorism, the legal provisions in this area have been limited. The legal basis for EU provision on terrorism are Articles 29 to $42 \mathrm{EU}^{7}$ otherwise known at Title VI EU. Further to these provisions two framework decisions ${ }^{8}$ and two joint actions ${ }^{9}$ have been enacted specifically addressing issues relevant to terrorism.

Council Framework Decision 2002/475/JHA ${ }^{10}$ on combating terrorism now applies not only to all 25 member states of the EU, (on the basis that any member state joining the EU has to take upon itself the acquis Union, or all the laws and developments of the laws in force within the Union at the time that it joins the Union, but also, pursuant to Article 12 of said Framework Decision, to Gibraltar, which is not in itself, or as part of the UK, a member of the EU. ${ }^{11}$ One of the first problems with regard to terrorism was the need for a common definition for terrorism, to be set out at an EU level, and applied in all EU member states. $^{12}$ Terrorism is therefore defined in Article 1 of Framework Decision 2002/475/JHA. Terrorism in the EU is now to include actions which "may seriously damage a country or an international organisation" which have the aim of "seriously intimidating a population", "unduly compelling a Government or international organisation to perform or abstain from performing any act", or "seriously destabilising or

\footnotetext{
${ }^{7}$ formerly known as Articles K.1 to K.14, of which more later in this paper.

${ }^{8}$ Council Framework Decision 2002/475/JHA of 3 June 2002 on combating terrorism OJ L22/6/2002, 164/3, and Council Framework Decision 2001/220/JHA of 15 March 2001 on the standing of victims in criminal proceedings, OJ L 22/3/2001, 82/1

${ }^{9}$ Joint Action 96/610/JHA on the creation of a Directory of specialist counter terrorism skills, OJ. L 273, 25.10.1995, p. 1, and Joint Action 98/733/JHA on making it a criminal offence to participate in a criminal organisation, OJ L 29/12/98, L 351/1

${ }^{10}$ Council Framework Decision 2002/475/JHA of 3 June 2002 on combating terrorism OJ L22/6/2002, $164 / 3$,

${ }^{11}$ the relevant member of the EU being the United Kingdom of Great Britain and Northern Ireland, which does not normally include the Isle of Man, the channel islands or Gibraltar. In contrast it is France Outremere, rather than France Maritime which has joined the EU, therefore territories such as French Guyana, Martinique, Réunion etc. are part of "France" for the purposes of EU membership and are fully involved in EU matters.

${ }^{12}$ For the purposes of Criminal law it must be recalled that the UK is itself comprised of a number of different legal jurisdictions, with, for example, different offences and processes operating on either side of the Scottish - English border.
} 
destroying the fundamental political, constitutional, economic or social structures of a country or an international organisation". For its part a terrorist group is defined as "a structured group of more than two persons, established over a period of time and acting in concert to commit terrorist offences". ${ }^{13}$ Offences linked with terrorist activities is defined as being aggravated theft, extortion or the drawing up of false administrative documents with a view to committing one of the offences defined in Article 1 of the Framework Decision. ${ }^{14}$

Offences against persons cover the doing, or the threatening to attack an individual in a way which may cause death, attack the physical integrity of a person, "kidnapping or hostage taking", are all included. Offences against institutions or property include the doing or threatening to "cause extensive destruction to a Government or public facility, a transport system, an infrastructure facility, including an information system, a fixed platform located on the continental shelf, a public place or private property likely to endanger human life or result in major economic loss". ${ }^{15}$ Also included is the seizure of any method of public or goods transport, "the release of dangerous substances, or causing fires, floods or explosions the effect of which is to endanger human life", or the "interfering with or disrupting the supply of water, power or any other fundamental natural resource the effect of which is to endanger human life". Of course the "manufacture, possession, acquisition, transport supply or use of weapons, explosives or of nuclear, biological or chemical weapons, " to include the "research to, and development of, biological and chemical weapons", or threatening to do so, is also to be deemed to be a terrorist offence under this Framework Decision. It is felt that this above definition is "unacceptably broad" and is likely to infringe Article 7 of the European Convention on Human Rights (ECHR), which requires that for a legal provision to be "lawful" under the ECHR that "an individual should be able to know" from reading the relevant document "what acts or omissions he/she can be held liable". ${ }^{16}$

In addition to the standardising of definitions throughout the EU, with the Framework Decision requiring national laws to be amended where differences between their provisions and those of the Framework Decision arise, the Framework Decisions required that EU member states to ensure that the offences referred to in the Framework Directive are

\footnotetext{
${ }^{13}$ Article 2.1 of Council Framework Decision 2002/475/JHA

${ }^{14}$ Article 3 of Council Framework Decision 2002/475/JHA

${ }_{15}$ Article 1(d) of Council Framework Decision 2002/475/JHA

${ }^{16}$ Douglas-Scott, Sionaidh; The rule of law in the European Union - Putting the security in the area of Freedom, Security and Justice, E.L.Rev.2004, 29(2), 219-242
} 
"punishable be effective, proportional and dissuasive criminal penalties, which may entail extradition". ${ }^{17}$ The level of these penalties are not however specified, but are to be reducible if any of the circumstances in Article 6 of the Framework Directive occur, namely, renouncing terrorist activity, together with providing specified types of assistance to the relevant administrative or judicial authorities. Inciting, aiding or abetting a terrorist offence, or attempting to commit a terrorist offence is also to be legislated for, if it has not done so already, in each of the EU member states, with member states being required to take all the necessary measures to create these offences. ${ }^{18}$ The reference to extradition is also of interest, as the EU's European Arrest Warrant is now fully operational ${ }^{19}$ throughout the EU, and also in Gibraltar.

Penalties for terrorism are not set out in the Framework Directive, with the EU merely requiring that "each Member State shall take the necessary measure to ensure that" the penalties are "effective, proportionate and dissuasive", which may also "entail extradition", with a reduction in penalty to be provided should an individual renounce terrorist activity, or provide "the administrative or judicial authorities with information which they would not otherwise have been able to obtain" with regard to preventing terrorism, or prosecuting other participants in the act of terrorism. ${ }^{20}$ Provisions must also be provided in national legislation for the liability ${ }^{21}$ and punishment ${ }^{22}$ of legal persons with regard to terrorism offences. The issue of jurisdiction and which EU member state is to prosecute for a terrorist offence is also covered, ${ }^{23}$ as is the issue of the granting of protection and assistance to witnesses,${ }^{24} \mathrm{a}$ matter which is also covered by the more broadly focused Council Framework Decision of $15^{\text {th }}$ March 2001 on the standing of victims in criminal proceedings. ${ }^{25}$

The Council Framework Decision on Terrorism is complimented by the Arrest Warrant Framework Decision, ${ }^{26}$ both documents having

\footnotetext{
${ }^{17}$ Article 5 of Council Framework Decision 2002/475/JHA

${ }^{18}$ Article 4 of Council Framework Decision 2002/475/JHA

${ }^{19}$ Council Framework Decision 2002/584/JHA of 13 June 2002 on the European arrest warrant and the surrender procedures between Member States, OJ L 190 of 18.07.2002

${ }^{20}$ Article 6 of Council Framework Decision 2002/475/JHA

${ }^{21}$ Article 7 of Council Framework Decision 2002/475/JHA

${ }^{22}$ Article 8 of Council Framework Decision 2002/475/JHA

${ }^{23}$ Article 9 of Council Framework Decision 2002/475/JHA

${ }^{24}$ Article 10 of Council Framework Decision 2002/475/JHA

${ }^{25}$ Council Framework Decision of $15^{\text {th }}$ March 2001 on the standing of victims in criminal proceedings (2001/220/JHA) OJ L82/1, 22.3.2001.

${ }^{26}$ Council Framework Decision of 13 June 2002 on the European Arrest Warrant and the Surrender Procedures between member States, O.J. 2002, L 190/1
} 
been passed exceptionally swiftly. ${ }^{27}$ This swiftness in passing of law was seen to be an exercise in exceptionally efficient law making, however there is a tension between "democratic accountability and efficiency", 28 with the lack of democratic input and control being a major concern, along with the issue of the rule of law and the protection of human rights, to legal academic commentators on this area of law. ${ }^{29}$

The Arrest Warrant Framework Decision for its part is seen as a "genuine paradigm shift in legal co-operation between Member States", a paradigm which will be expected to be seen in the operation of the Council Framework Decision on Terrorism. Traditionally states have been wary of each others laws, with the norm being that one state not enforcing the rulings of another jurisdiction, unless specifically agreed to do so, under narrowly drafted extradition treaties. This document however operates on the principle, with some exceptions, that EU member states will "automatically recognise each other's judicial decisions ordering the arrest of a person". ${ }^{30}$ This approach reflects a "high level of confidence between Member States". ${ }^{31}$ It should be noted that political offences are not one of the specified exceptions to the Arrest Warrant Framework Decision, bringing an end to "an era of sympathy with politically motivated rebellion. ${ }^{32}$ It is felt by some that the lack of Human Rights provisions at an EU level is mitigated given that all member states of the EU are bound by the provisions of the European Convention on Human Rights, which, through interpretation by the European Court of Human Rights "in effect" leads "to quite a high level of protection". 33

In addition is should be noted that Europol, Eurojust ${ }^{34}$ and the European Judicial Network in Criminal Matters ${ }^{35}$ (set up pursuant to a joint action), ${ }^{36}$ all have a part to play when it comes to combating terrorism. Europol's capacity to deal with terrorism issues were

\footnotetext{
${ }^{27}$ Wouters, Jan and Naert, Frederik; Of arrest warrants, terrorist offences and extradition deals: an appraisal of the EU's main criminal law measures against terrorism after "11 September", CMLRev. 41: 909-935, 2004

${ }^{28}$ Op. cit. footnote no. 16.

${ }^{29}$ Sionaidh Douglas-Scott; The rule of law in the European Union - Putting the security in the area of Freedom, Security and Justice, E.L.Rev.2004, 29(2), 219-242 and Jan Wouters and Frederik Naert; Of arrest warrants, terrorist offences and extradition deals: an appraisal of the EU's main criminal law measures against terrorism after "11 September", CMLRev. 41: 909-935, 2004

${ }^{30}$ Op. cit. footnote no. 27.

${ }^{31}$ Ibid.

${ }^{32}$ Ibid.

33 Ibid.

${ }^{34} \mathrm{http}: / /$ www.eurojust.eu.int

${ }^{35}$ http://www.ejn-crimjust.eu.int

${ }^{36}$ Joint Action of 29 June 1998 adopted by Council on the basis of Article K.3 of the Treaty on European Union, on the creation of a European Judicial Network, (98/48/JHA), OJ L. 191/4
} 
"augmented" subsequent to $11 / 11$ by the creation of a team of "counter terrorist experts" at Europol. ${ }^{37}$ This team operates through "agreements with the US", laising with Eurojust, and the development of joint investigation teams between law enforcement bodies in different member states. ${ }^{38}$ This is all complimented by judicial and police co-operation, peer review of national legal systems, and the drafting of a "common scale for assessing threats to visiting public figures".

Europol causes lawyers concern as its control mechanisms are "extremely fragmented and lacking in transparency", 40 operating with "minimal supervision", with a "lack of independent scrutiny and management", from either EU bodies or from the member states of the EU. These criticisms of Europol, staffed by law enforcement officers, of a lack of judicial and parliamentary scrutiny is also echoed with regard to Eurojust, staffed by judges, with regard to the lack of parliamentary control. ${ }^{42}$ It should also be noted at this point that an Anit-terrorism Coordinator has been appointed, and a "declaration on combating terrorism and on solidarity against terrorism" has been adopted. ${ }^{43}$ The Schengen Information system, originally set up pursuant to the Schengen Convention is also plays its part in the EU's counter terrorism measures.

More broadly within the PJCCM pillar, the creation of a European Public Prosecutor's office is being debated. Should such an office be created it would undoubtedly have an effect on the development of the EU's counter terrorism measures. On the legislative front, two other important documents, both passed pursuant to the post-Maastricht, preAmsterdam provisions on JHA, as reflected in their titles in their reference to K.3, (now, as amended, Article $31 \mathrm{EU}$ ), are the Joint Action 98/733/JHA, dealing with membership of a criminal organisation, ${ }^{44}$ and Joint Action 96/610/JHA setting up a directory of specialized counterterrorist competences, skills and expertise. ${ }^{45}$

\footnotetext{
${ }^{37}$ Op. cit. footnote no. 16.

${ }^{38}$ Op. cit. footnote no. 27.

${ }^{39}$ Ibid.

${ }^{40}$ Op. cit. footnote no. 16.

${ }^{41}$ Ibid.

${ }^{42}$ Ibid.

${ }^{43}$ Op. cit. footnote no. 27.

${ }^{44}$ 98/733/JHA Joint Action of 21 December 1998 adopted by the Council on the basis of Article K.3 of the Treaty on European Union, on making it a criminal offence to participate in a criminal organisation in the Member States of the European Union, OJ L 351.1, 29.12.98

45 96/610/JHA: Joint Action of 15 October 1996 adopted by the Council on the basis of Article K.3 of the Treaty on European Union concerning the creation and maintenance of a Directory of specialized counter-terrorist competences, skills and expertise to facilitate counter-terrorist cooperation between the Member States of the European Union, OJ. L 273, 25/10/1996, p. 1.
} 


\section{The EU legal framework in which the terrorism provisions are set}

The legal framework within which the EU terrorism and terrorist related provisions have been enacted have a strong influence on the operation of the law in this area. This is particularly so as the nature of law in the PJCCM pillar of the EU is not like that of the much more coherent and effective EC law of the first pillar of the EU. The flaws in the PJCCM legal system have been widely accepted, with radical changes having been written into the proposed EU Constitution, which had, unfortunately for lawyers interested in this area, been mired by political considerations.

The legal tools in the area of Justice and Home Affairs have changed in recent years. Justice and Home Affairs was initially legislated for under the Maastricht Treaty in 1992, which used the numbering A, B, $\mathrm{C}$ etc, hence the numbering for Justice and Home Affairs once having the numbering K.1, $2 \ldots$ etc. The Maastricht treaty, also known as the Treaty on European Union provided, in article K.3, that the legal tools in the area of JHA were to be joint positions, joint actions and conventions "which it shall recommend to the Member States for adoption in accordance with their respective constitutional requirements". Conventions are also known as International Treaties, and are the principal legal tool of International law. International law commonly splits into Public International law, being agreements between states, dealing with relationships between those states, and Private International law, being agreements between states, but dealing with relationships between their citizens or subjects, on topics such as international contracts, or family law cases. International law impacts on national law depending on whether the relevant national jurisdiction is monist, dualist, or a hybrid of both. This is what is meant by "their respective constitutional requirements". A monist legal jurisdiction sees no difference between national law and international law. Japan would be a typical example of this, although it appears to be reviewing its position on this point. ${ }^{46}$

The UK is a typical example of a dualist legal system, seeing international law and domestic law as being two distinct jurisdictions. For the UK international law only affects the domestic jurisdictions ${ }^{47}$ after

\footnotetext{
${ }^{46}$ See the Japanese case, Kyoto Neckties, which deals with the relationship between Japanese law and World Trade Organisation law: Judgment of June 29, 1984, Kyoto District court, 31 Shōmu Geppō 207, which seems to have been endorsed by the Judgment of Feb. 6, 1990, Supreme Court, slip op.

${ }^{47}$ The UK, unlike its fellow EU member states, is in fact a number of domestic legal jurisdictions, inter alia, 1. England and Wales, 2. Scotland, and 3. Northern Ireland.
} 
domestic legislation has been passed implementing the international legal commitments into national law. Most EU member states are a hybrid between these two extremes. It should be noted however that EC law, and also PJCCM law, are not classified as International law, although that is clearly their origin. EC law is seen as being sui juris, or one of a kind, and automatically affects UK law (those jurisdictions within the $\mathrm{UK}^{48}$ who have joined the $\mathrm{EC}^{49}$ ). EU PJCCM law is currently under development, and while it still has to be properly classified, it can be seen as being a hybrid between EC law and International law, with one of its legal tools, the Convention, or International Treaty being clearly an International law legal tool. The institutions of the $\mathrm{EC}$, specifically the Council, Commission, ECJ and the European Parliament have been "borrowed" by the EU for its purposes. However these EC institutions operate in a different manner in the pillar II (CFSP) and Pillar III (PJCCM) policy areas than they do under Pillar I, EC matters. Under PJCCM while the EC's principal court, the European Court of Justice (ECJ), which is based in Luxembourg, was to continue to deal with disputes between member states, or between the institutions and the member states in JHA matters, unlike under EC law, there was no access by an individual to the ECJ in this policy area.

The area of JHA was however radically altered by the Amsterdam Treaty, which came into force in 1997, with a large part of Justice and Home Affairs being moved from pillar 3 (which was then to become the PJCCM pillar), to pillar 1, the EC, and becoming Title IV EC, "Visas, Asylum, Immigration and other matters dealing with the Free Movement of Persons". It should be pointed out at this stage that the free movement of EC nationals in their capacity as workers has always been a core EC policy area. The free movement of persons to be covered in the new Title IV being the free movement of non-EC nationals, or as referred to in EC legal texts, $3^{\text {rd }}$ country nationals. In addition, while it is not referred to in the title to Title IV, judicial co-operation in civil matters (as opposed to criminal matters) was transferred from pillar III to pillar I of the EU. The consequences of this was that pillar I matters operate in a much more coherent legal framework than would be the case in Pillar III, with the very clear principles of supremacy and direct effect permeating all EC law, and the very clear legal tools of EC regulations, directives and decisions being used here, in contrast to the more difficult legal tools being used in Pillar III of the EU. In addition access to the ECJ for

\footnotetext{
${ }^{48}$ The United Kingdom of Great Britain and Northern Ireland

${ }^{49}$ the Isle of Man, and the Channel Islands are not in the EC/EU, and are therefore not subject to either EC or EU legal provisions.
} 
individuals is clearer in Pillar I, although for ex-JHA matters, is not the same as for the balance of EC law.

Normally any court or tribunal of an EC member state before whom an EC legal point is being argued, can if they are unclear about the law, make a reference to the ECJ under Article 234 EC (ex. Article 177 EC) to ask for clarity on the legal point in issue. Having received the ruling from the ECJ, which then applies throughout the EC, the local court or tribunal then applies the law to the facts of the case. Under Title IV EC only the court or tribunal of final appeal can make the reference. ${ }^{50}$ This would mean that a case, in civil law, would have to be appealed all the way to the House of Lords, adding time and expense, before a reference could be made to the ECJ, thereby compromising the quality and unity of interpretation of the law in this area, in comparison to the balance of EC law.

As a corollary to this issue, the Amsterdam Treaty inserted access to the ECJ in Pillar III, now to be known as PJCCM, in Article 35 EU, but provided for 3 options, at the selection of each member state. These work out as no access to the ECJ for PJCCM matters, the current UK position, access from any court or tribunal, the mainstream EC method, access only from the highest court or tribunal, which if this option applied in Scotland would be High Court of Justiciary, unless it issue in question is a devolution issue, as defined by the Scotland Act 1998, then the highest court would be the Judicial Committee of the Privy Council. ${ }^{51}$ These devolution issues would normally be about Human Rights issues, not a matter for the EU, but rather the International law based organisation of the Council of Europe, based in Strasbourg, of which more later. In England and Wales, the highest court of appeal in Criminal cases would be the House of Lords. Three options for access to the ECJ in PJCCM matters can only lead to what many are calling a Multi-speed Europe or "variable geometry".

A further "variable geometry" was added to the mix by the Amsterdam Treaty, when it integrated the pre-existing international law treaty, the Schengen Convention 1990, which implemented the Schengen Agreement 1985 into mainstream EU law. The Amsterdam Treaty integrated the Schengen Convention into both pillar I EU, the EC, and Pillar III, PJCCM, with those bits, which most closely fit the relevant pillar being integrated into those pillars. However two EC/EU member

\footnotetext{
${ }^{50}$ Under Article 64 EC.

${ }^{51}$ The Judicial Committee of the Privy Council is in reality is the House of Lords in a different formation to the usual.
} 
states where not members of the pre-existing Schengen Convention, and wished to continue outside its framework, namely, the UK and the Republic of Ireland. In addition two member states of the Schengen Convention were not, and did not want to join the EC/EU, namely Norway and Iceland. For these latter countries all Schengen commitments must necessarily remain as International law obligations.

To add to the mix, Denmark, which was very happy with Schengen as International law, did not want any of it to form part of its EC law commitments. Denmark was happy to have part of Schengen as pillar III, but those parts which for everybody else was to become EC law, namely issues dealing with visas, asylum, immigration and other matters dealing with the free movement of $3^{\text {rd }}$ country nationals, were to remain as international law commitments for Denmark. This approach reflected the very differing nature of the more robust and effective EC law in comparison to the looser EU law and the very difficult to enforce nature of International law. All of these variations were dealt with by way of protocols $^{52}$ attached to the Amsterdam Treaty. It should also be noted that the Amsterdam Treaty renumbered both the EC and EU treaty, just to add to the confusion.

Not only is Schengen relevant to terrorism issues, but so too is the International law based Europol Convention 1995. This document, which all, and only, EU member states are party to, set up the European Police Office in the Hague, Netherlands, ${ }^{53}$ not to be confused with Interpol's European Committee, based in Lyon, France. It will therefore be with some relief to readers that the later Nice Treaty, which came into force in 2003 had little effect on this policy area, with the proposed EU Constitution, should it ever come into force, being the next legal document to develop this policy area.

The post -Amsterdam version of the Treaty on European Union provides, at Article $34 \mathrm{EU}$, that the legal tools are to be common positions, framework decisions, decisions and conventions. Framework Decisions are defined as being "binding upon the Member States as to the result to be achieved but shall leave to the national authorities the choice of form and methods". To a certain extent these Framework Decisions resemble EC Directives, however they differ from EC Directives as Framework Decisions are not to have direct effect. Direct effect is a very important legal effect used to add to the coherence of EC law. Framework decisions are also to be used for the approximation of the laws of EU

\footnotetext{
${ }^{52}$ Protocols are legally biding exceptions to treaties

${ }^{53} \mathrm{http}: / / \mathrm{www}$.europol.eu.int
} 
member states, unlike EC law, which is said to be used for the purpose of "harmonisation" or at times unification of law.

\section{Proposals for reform under the proposed EU Constitution}

In addition to the variable geometry issues which currently arise, as discussed above, due to the various protocol opt outs, which will continue with a wide range of protocols having been attached to the proposed EU Constitution, a number of very serious problems arise with the current structure of PJCCM provisions. The three options for access to the ECJ, under Article $35 \mathrm{EU}$, is less than satisfactory. In addition the nature of the legal documents operating in PJCCM, together with the lack of clarity as to the exact nature of PJCCM law is causing serious concerns. The problems of International law is permeating the area of PJCCM, in particular as one of the legal tools is the Convention, or International Treaty, with its monist/dualist constraints. A number of EU jurisdictions require referenda in order to accede to certain International treaties "in accordance with their respective constitutional requirements", thereby causing uncontrollable problems in the developing of law in this area. The other PJCCM legal tools are also not without their own problems. Europol is also operating in the relative legal wilderness of International law, unlike many other European legal structures, such as the European Central Bank, which is operating within the clearly defined and easily operateable and enforceable EC legal framework. The reason for this legal problem is national politics, and the reluctance of EU member states to cede sovereignty to the supranational legal entity of the EC in policing and criminal law matters. This is again the problem being encountered with the proposed, signed but not yet in force EU Constitution.

The "EU Constitution" is not, despite its name, a constitution, but another International Treaty. Unlike earlier EC/EU treaties, the EU Constitution does not propose amending earlier EC or EU treaties, but proposes creating a new EU, with one pillar, integrating PJCCM provisions into the main body of the "new EU law", benefiting from the principles of supremacy and direct effect, with the standard method of approaching the ECJ applying to this policy area, and utilising the same legal tools as will be used for what are now the main policy areas of the EC. These new legal tools, not currently in use anywhere in the EC or EU legal structure, will be European laws, European Framework laws, European regulations and European decisions, pursuant to Article I-33 of the EU Constitution. In addition it is intended to give legal capacity to the 
EU, something only the EC, and not the current EU, enjoys. ${ }^{54}$ The European Commission is particularly anxious to "mainstream" PJCCM matters in this way, in order to ensure that the law is better constructed and thereby more effective in this area. This however has serious political consequences as there will be, as a consequence further transfer of power from national governments and judiciary to "Brussels".

The EU Constitution, as currently drafted, has four chapters, denoted in Roman numerals. It exhibits very much a "cut and paste" approach to legislative drafting, with Title III being very much the current EC treaty, cut and pasted in, with some amendments. Of particular relevance to the issue of terrorism is the fact that Title II of the EU Constitution operates as a "cut and paste" of the current Charter of Rights and Fundamental Freedoms, otherwise known as the Nice Charter. ${ }^{55}$ The Nice Charter currently sits in the vague area of EU law, expressing many fine objectives, but not being regarded as "hard" law, of any use in any court. The moving of its provisions into Title II EU would make its provisions much more effective. This is important as the neither the current EC nor EU are members of the European Convention on Human Rights. The EU cannot be a member of any organisation, as it has no legal capacity to sign anything. Currently any agreement which the EU wishes to participate in within the field of PJCCM has to be signed by each member states of the EU in their own capacity. The EC does have legal capacity, but the EC does not operate any of the PJCCM provisions.

This has caused serous problems in the area of commercial law, with a very robust judicial row having developed between the German Constitutional Court, ${ }^{56}$ and the ECJ as to the supremacy of EC law in the absence of any concept of Human Rights in EC law. ${ }^{57}$ The highest court in Germany refused, for some time to recognise EC law as being supreme to the German Constitution, as there was protection for human rights in the German Constitution, but not in the EC Treaty. The judicial argument ended up with the ECJ saying that it, the ECJ "has consistently held that fundamental rights are an integral part of the general principles" of EC law. The subsequent developments of such fundamental rights to meet the requirements of a commercial law case have not, however, been without

\footnotetext{
${ }^{54}$ Under Article 281 EC.

${ }^{55}$ Charter of Fundamental Rights of the European Union, OJ 2000 C364/01, the "Nice" charter.

${ }^{56}$ the Bundesverfassundsgericht.

${ }^{57}$ The cases here were International Handelsgesellschaft $m b H$ v. Enifurh-und Vorratsstelle für Getreide und Futtermittel (Case 2 BvL 52/71), before the Bundesverfassundsgericht, the International Handelsgesellschaft case before the ECJ, (Case 11/70, [1970] ECR 1125), Re the application of Wünsche Handelsgesellschaft (Case 2 BvR 197/83) before the Bundesverfassundsgericht, and Case 46/87, Hoechst v. Commission, [1989] ECR 2859.
} 
their problems, as evidenced by the ruling in Opinion 2/94. The ECJ in Opinion $2 / 94^{58}$ the ECJ stated that the EC had no legal capacity assigned to it by its member states to sign the European Convention on Human Rights. In addition the European Convention on Human Rights only has states as members. The EC is not a state. However other organisations which deal with the core economic issues of the EC have managed to accommodate the EC as a member, not least the World Trade Organisation. ${ }^{59}$ This was, however, all before criminal matters became such a core "Brussels" issue.

The current situation therefore is that while each of the EC/EU member states are members of the European Convention on Human Rights, and operate its provisions within their domestic jurisdictions, there is no interaction between either the supranational EC legal jurisdiction or the intergovernmental EU- PJCCM jurisdiction with the European Convention on Human Rights, or its court, the European Court of Human Rights, (ECHR) which is based in Strasbourg.

The absence or lack of development of such fundamental rights is even more of an issue in situations where police and criminal matters arise. The new EU Constitution, should it ever come into force, in attempting to address this very serious lacuna expresses the intention of the "new EU" to accede to the European Convention on Human Rights in Article I-9.2 EUC. Such a provision, once ratified within the document by all member states of the EC/EU would thereby give power to the "new EU" to do so.

\section{Conclusion}

Unlike in EC law, it is not sufficient in PJCCM law, to ask what is the content of the legal document in order to get the full legal picture, as, for example in the policy area of anti-terrorist measures. It is also important to understand the context within which the particular legal tool operates in order to fully understand its legal effect. The defective constitutional framework within which PJCCM has to operate has been graphically referred to by Gormley as being "like a colander to such an extent as to make any concept of a European Union in fact a house built on sand, appearing solid but without the necessary foundation piles to

\footnotetext{
${ }_{58}^{58}$ Opinion 2/94 (re ECHR) [1996] ECR I-1759; [1996] 2 CMLR 265

${ }^{59} \mathrm{http}: / /$ www.wto.org
} 
make it a credible entity". ${ }^{60}$ The fact that the Greek temple of the EU, as envisaged by Curtain has not yet come down around our ears is very much due to good will of all the member states of the EU, with the intention of putting in the badly needed structural foundations, in particular for PJCCM being behind the drafting of the relevant provisions of the proposed EU Constitution. It is down to the internal politics of the EU member states whether either the proposed EU Constitution, or the relevant PJCCM parts of it ever come into force.

${ }^{60}$ Gormely, Laurence W.; Reflections on the Architecture of the European Union after the Treaty of Amsterdam, Chapter 4 in "Legal Issues of the Amsterdam Treaty" O'Keefe \& Twomey, (eds.), Hart Publishing, 1999. 